\title{
Mercury Cyanamide / Carbodiimide Networks: Synthesis and Crystal Structures of $\mathrm{Hg}_{2}(\mathrm{NCN}) \mathrm{Cl}_{2}$ and $\mathrm{Hg}_{3}(\mathrm{NCN})_{2} \mathrm{Cl}_{2}$
}

\author{
Xiaohui Liu and Richard Dronskowski \\ Institut für Anorganische Chemie der RWTH Aachen, Prof.-Pirlet-Str. 1, D-52056 Aachen \\ Reprint requests to Prof. Dr. R. Dronskowski. E-mail: drons@HAL9000.ac.rwth-aachen.de \\ Z. Naturforsch. 57 b, 1108-1114 (2002); received June 10, 2002 \\ Mercury Cyanamide / Carbodiimide Chloride, Inorganic Polymer, 2D Network \\ We report about the synthesis and crystal structure determination of $\mathrm{Hg}_{2}(\mathrm{NCN}) \mathrm{Cl}_{2}\left(P 2_{1} / c\right.$ \\ (No. 14), $Z=4, a=806.7(1), b=907.1(2), c=788.0(1) \mathrm{pm}, \beta=106.446(3)^{\circ}, 1374$ independent \\ reflections, 67 variables, $R_{1}=0.0463$ ) and $\mathrm{Hg}_{3}\left(\mathrm{NCN}_{2} \mathrm{Cl}_{2}\left(P c a 2_{1}\right.\right.$ (No. 29), $Z=4, a=702.0$ (2), \\ $b=1078.5(2), c=1050.3(2) \mathrm{pm}, 1977$ independent reflections, 71 variables, $\left.R_{1}=0.0380\right)$. Both \\ compounds contain infinite - $\mathrm{Hg}-\mathrm{NCN}-\mathrm{Hg}$ - zigzag chains which are linked by additional $\mathrm{Hg}$ \\ atoms to result in two-dimensional frameworks characterized by 20 -membered rings sharing \\ edges. The remarkably flexible structural backbone $\left[\mathrm{Hg}_{3}(\mathrm{NCN})_{2}\right]^{2+}$ hosts additional $\mathrm{Cl}^{-}$anions \\ and $\mathrm{HgCl}_{2}$ molecules in $\mathrm{Hg}_{2}(\mathrm{NCN}) \mathrm{Cl}_{2}$ but only $\mathrm{Cl}^{-}$anions in $\mathrm{Hg}_{3}\left(\mathrm{NCN}_{2} \mathrm{Cl}_{2}\right.$, by that reaching \\ a high packing efficiency in both cases. While $\mathrm{Hg}_{2}(\mathrm{NCN}) \mathrm{Cl}_{2}$ exclusively contains carbodiimide \\ $\mathrm{N}=\mathrm{C}=\mathrm{N}^{2-}$ species, $\mathrm{Hg}_{3}(\mathrm{NCN})_{2} \mathrm{Cl}_{2}$ is the first structural example of an inorganic network built \\ up from both carbodiimide $\mathrm{N}=\mathrm{C}=\mathrm{N}^{2-}$ and cyanamide $\mathrm{N}-\mathrm{C} \equiv \mathrm{N}^{2-}$ groups.
}

\section{Introduction}

Over the last decade, synthetic and crystallographic as well as theoretical studies on solid-state cyanamide chemistry have progressed enormously. Besides the relatively simple crystal chemistry of the cyanamides involving alkaline or alkaline-earth metal cations [1 - 3], which is easily understood in terms of electrostatic interactions, effects of covalent bonding in the main-group and transition-metal representatives allow for greater structural varieties. For example, we mention chain structures formed in $\mathrm{Ag}_{2} \mathrm{NCN}$ [4], in mercury carbodiimide $\mathrm{HgNCN}(\mathrm{I})$ [5] and in mercury cyanamide $\mathrm{HgNCN}(\mathrm{II})$ [6]; in addition, there are three-dimensional bonding arrangements in $\mathrm{In}_{2.24}(\mathrm{NCN})_{3}$ [7], $\mathrm{ZnNCN}$ [8] and in $\mathrm{Si}(\mathrm{NCN})_{2}$ [9], which bear striking resemblance with interpenetrating networks such as of the $\beta$ cristobalite $\left(\mathrm{SiO}_{2}\right)$ type.

When it comes to the aufbau of crystalline porous materials, various organic or inorganic spacer ligands coordinating to metal cations have been explored; here, N-containing spacers such as pyridine and cyano ligands were typically and successfully used [10]. On the other side, the probably smallest $\mathrm{N}, \mathrm{N}^{\prime}$-type ligand - the $\mathrm{NCN}^{2-}$ anion, either in carbodiimide $\mathrm{N}=\mathrm{C}=\mathrm{N}^{2-}$ or in cyanamide $\mathrm{N}-\mathrm{C} \equiv \mathrm{N}^{2-}$ form - had not been expected to form pore or chan- nel structures. It is also clear that the metal cation plays a decisive role for the total structure since its preferences for coordination number, coordination geometry and chemically matching ligands must be taken into account. For $\mathrm{Hg}(\mathrm{II})$, twofold linear coordination is observed throughout [11] but there are also some examples of 4- and 6-coordinated $\mathrm{Hg}$ (II) centers with longer interatomic distances [12]. To the best of our knowledge, no metal-cyanamide polymeric networks have been reported so far.

In an attempt to grow high-quality $\mathrm{HgNCN}$ single crystals by slow diffusion, we unexpectedly found two such inorganic polymers involving $\mathrm{Hg}^{2+}$ and $\mathrm{NCN}^{2-}$ in crystalline form. Here, we describe both synthesis and crystal structures of $\mathrm{Hg}_{2}(\mathrm{NCN}) \mathrm{Cl}_{2}$ and $\mathrm{Hg}_{3}(\mathrm{NCN})_{2} \mathrm{Cl}_{2}$ and further discuss the coordination situation as well as the two-dimensional frameworks observed in the two compounds. The seemingly rather flexible coordination of the $\mathrm{NCN}^{2-}$ anion and $\mathrm{Hg}^{2+}$ cation allows for differing capacities to host guest species within the framework.

\section{Experimental Section}

\subsection{Synthesis}

Two 0.1 molar aqueous solutions of $\mathrm{HgCl}_{2}$ and $\mathrm{H}_{2} \mathrm{NCN}$ were filled into a "U-form" glass the left and right parts 
Table 1. Crystallographic data for $\mathrm{Hg}_{2}(\mathrm{NCN}) \mathrm{Cl}_{2}$.

\begin{tabular}{|c|c|}
\hline Formula; molar mass & $\mathrm{Hg}_{2}(\mathrm{NCN}) \mathrm{Cl}_{2} ; 512.11 \mathrm{~g} / \mathrm{mol}$ \\
\hline $\begin{array}{l}\text { Crystal color } \\
\text { and form }\end{array}$ & Colorless hexagon \\
\hline Lattice constant & $\begin{array}{l}a=806.7(1) \mathrm{pm} \\
b=907.1(2) \mathrm{pm} \\
c=788.0(1) \mathrm{pm} \\
\beta=106.446(3)^{\circ}\end{array}$ \\
\hline Cell volume & $553.0(2) \cdot 10^{6} \mathrm{pm}^{3}$ \\
\hline Space group; $Z$ & $P 2{ }_{1} / c$ (No. 14$) ; 4$ \\
\hline X-ray density & $6.151 \mathrm{~g} / \mathrm{cm}^{3}$ \\
\hline$F(000)$ & 856 \\
\hline Diffractometer & $\begin{array}{l}\text { Bruker SMART CCD diffracto- } \\
\text { meter with Mo-K }{ }_{\alpha} \text { radiation, } \\
\text { graphite monochromator }\end{array}$ \\
\hline Temperature & 293(1) K \\
\hline No of reflections & $4569\left(R_{\mathrm{eq}}=0.0557\right)$ \\
\hline Independent refls & 1374 \\
\hline Octants; max. $\theta$ & $\begin{array}{l}-10 \leq h \leq 10,-11 \leq k \leq 12, \\
-10 \leq l \leq 10 ; 28.30^{\circ}\end{array}$ \\
\hline Absorption coeff. & $56.2 \overline{80} \mathrm{~mm}^{-1}$ \\
\hline Abs. correction & numerical, indexed faces: \\
\hline Crystal dimension & $\begin{array}{l}(100) \leftrightarrow(\overline{1} 00),-0.014 \leftrightarrow 0.019 \mathrm{~mm} \\
(010) \leftrightarrow(0 \overline{1} 0),-0.022 \leftrightarrow 0.020 \mathrm{~mm} \\
(001) \leftrightarrow(00 \overline{1}),-0.042 \leftrightarrow 0.055 \mathrm{~mm}\end{array}$ \\
\hline Structure solution & Direct Methods (SHELXS-97) \\
\hline Structure refinement & $\begin{array}{l}\text { Least-squares method on } F^{2} \text {, } \\
\text { Full matrix }\end{array}$ \\
\hline No. of intensities & 1374 \\
\hline No. of variables & 67 \\
\hline No. of restraints & 0 \\
\hline Weighting scheme & $\begin{array}{l}w=1 /\left[\sigma\left(F_{0}^{2}\right)(0.0581 P)^{2}\right] \\
\text { where } P=\left(\max \left(F_{0}^{2}, 0\right)+2 F_{0}^{2}\right) / 3\end{array}$ \\
\hline $\begin{array}{l}\text { Min., max. residual } \\
\text { electron density }\end{array}$ & $\begin{array}{l}-1.478,6.961 \mathrm{e} / \AA^{3} \\
\text { (proximity of } \mathrm{Hg} \text { ) }\end{array}$ \\
\hline$R_{1}, w R_{2}$ & $0.0463,0.1103$ \\
\hline Goodness of fit & 0.888 \\
\hline
\end{tabular}

of which were separated from each other by a $d=2 \mathrm{~cm}$ pottery filter of $4 A$ type. The glass was held at room temperature for $1 \mathrm{~d}$ after which a white powder, later identified as $\mathrm{HgNCN}(\mathrm{II})$, precipitated at both sides. Upon washing, two differently shaped types of colorless crystals were found within the main phase $\mathrm{HgNCN}(\mathrm{II})$. Those of a regular hexagon form were later identified to be $\mathrm{Hg}_{2}(\mathrm{NCN}) \mathrm{Cl}_{2}$ and predominate on the side of the $\mathrm{HgCl}_{2}$ solution; the rectangular plates are formed by $\mathrm{Hg}_{3}(\mathrm{NCN})_{2} \mathrm{Cl}_{2}$ and show up mainly on the $\mathrm{H}_{2} \mathrm{NCN}$ side. After drying in air, some selected crystals turned out to be suitable for X-ray single crystal measurement.

\subsection{Single crystal structure determination}

Selected crystals of $\mathrm{Hg}_{2}(\mathrm{NCN}) \mathrm{Cl}_{2}(0.033 \times 0.042$ $\left.\times 0.097 \mathrm{~mm}^{3}\right)$ and $\mathrm{Hg}_{3}(\mathrm{NCN})_{2} \mathrm{Cl}_{2}(0.07 \times 0.04 \times$ $0.02 \mathrm{~mm}^{3}$ ) were mounted on the tips of glass fibers. A set
Table 2. Positional parameters and isotropic displacement parameters $\left(\mathrm{U}_{\mathrm{eq}}\right.$ in $\mathrm{pm}^{2}$, a third of the trace of the orthogonalized $\mathrm{U}_{\mathrm{ij}}$ tensor) for $\mathrm{Hg}_{2}(\mathrm{NCN}) \mathrm{Cl}_{2}$ (standard deviations in parentheses).

\begin{tabular}{llllll}
\hline Atom & W.-Site $x$ & $y$ & $z$ & $\mathrm{U}_{\text {eq }}$ \\
\hline $\mathrm{Hg}(1)$ & $4 e$ & $0.1093(1)$ & $0.82183(8)$ & $0.2337(1)$ & $259(2)$ \\
$\mathrm{Hg}(2)$ & $2 d$ & $1 / 2$ & 0 & $1 / 2$ & $239(3)$ \\
$\mathrm{Hg}(3)$ & $2 b$ & $1 / 2$ & 0 & 0 & $541(5)$ \\
$\mathrm{Cl}(1)$ & $4 e$ & $0.4907(7)$ & $0.7527(6)$ & $0.2527(7)$ & $306(11)$ \\
$\mathrm{Cl}(2)$ & $4 e$ & $0.8009(6)$ & $0.0217(6)$ & $0.0761(7)$ & $319(12)$ \\
$\mathrm{N}(1)$ & $4 e$ & $0.234(2)$ & $0.990(2)$ & $0.399(2)$ & $225(36)$ \\
$\mathrm{C}$ & $4 e$ & $0.135(3)$ & $0.086(2)$ & $0.424(2)$ & $228(46)$ \\
$\mathrm{N}(2)$ & $4 e$ & $0.035(2)$ & $0.176(2)$ & $0.453(2)$ & $271(38)$ \\
\hline
\end{tabular}

of X-ray intensities was collected for each compound with a Bruker SMART-CCD diffractometer using graphite-monochromatized Mo- $K_{\alpha}$ radiation at $T=20(1){ }^{\circ} \mathrm{C}$ and the aid of the SMART and SAINT software packages [13].

In both cases, a total sphere of data was collected to allow for absorption corrections by means of faceindexing $\left(\mathrm{Hg}_{2}(\mathrm{NCN}) \mathrm{Cl}_{2}\right)$ and the empirical SADABS method $\left(\mathrm{Hg}_{3}(\mathrm{NCN})_{2} \mathrm{Cl}_{2}\right)$. The crystal structures were then solved by Direct Methods and refined by alternating cycles of (difference) Fourier syntheses and fullmatrix least-squares refinements with SHELXS-97 and SHELXL-97 [14]*.

\section{Results}

\subsection{The crystal structure of $\mathrm{Hg}_{2}(\mathrm{NCN}) \mathrm{Cl}_{2}$}

All relevant crystallographic data of the final refinement of $\mathrm{Hg}_{2}(\mathrm{NCN}) \mathrm{Cl}_{2}$ are summarized in Table 1 whereas Tables 2 and 3 offer the positional and isotropic as well as anisotropic displacement parameters; important bond distances and angles are given in Table 4.

The coordination motifs in $\mathrm{Hg}_{2}(\mathrm{NCN}) \mathrm{Cl}_{2}$ are offered in Fig. 1 by means of labeled displacement ellipsoids. The $\operatorname{Hg}(1)$ atom is bonded to two nitrogen atoms from crystallographically identical $\mathrm{NCN}^{2-}$ units in a nearly linear arrangement, that is $\mathrm{Hg}(1)$ $\mathrm{N}(1)=207.0(16) \mathrm{pm}, \mathrm{Hg}(1)-\mathrm{N}(2)=207.4(16) \mathrm{pm}$ and $\mathrm{N}(1)-\mathrm{Hg}-\mathrm{N}(2)=172.4(7)^{\circ}$. The $\mathrm{Hg}(1)$ s together with the $\mathrm{NCN}^{2-}$ units form infinite zigzag chains along the $b$ axis, the $\mathrm{NCN}^{2-}$ unit acting as a $\mu$-bridging ligand. $\operatorname{Hg}(2)$, sitting on the center of inversion

\footnotetext{
*Details may be obtained from: Fachinformationszentrum Karlsruhe, D-76344 Eggenstein-Leopoldshafen (Germany), by quoting the registry numbers CSD-412608 $\left(\mathrm{Hg}_{2}(\mathrm{NCN}) \mathrm{Cl}_{2}\right)$ and CSD-412609 $\left(\mathrm{Hg}_{3}(\mathrm{NCN})_{2} \mathrm{Cl}_{2}\right)$.
} 


\begin{tabular}{llllrrr}
\hline Atom & $\mathrm{U}_{11}$ & $\mathrm{U}_{22}$ & $\mathrm{U}_{33}$ & \multicolumn{1}{c}{$\mathrm{U}_{23}$} & \multicolumn{1}{c}{$\mathrm{U}_{13}$} & \multicolumn{1}{c}{$\mathrm{U}_{12}$} \\
\hline $\mathrm{Hg}(1)$ & $258(4)$ & $207(4)$ & $283(4))$ & $-35(4)$ & $28(3)$ & $-47(4)$ \\
$\mathrm{Hg}(2)$ & $145(5)$ & $270(6)$ & $278(6)$ & $-36(5)$ & $22(4)$ & $-3(5)$ \\
$\mathrm{Hg}(3)$ & $196(6)$ & $931(14)$ & $478(9)$ & $-57(9)$ & $65(6)$ & $-140(8)$ \\
$\mathrm{Cl}(1)$ & $362(28)$ & $258(28)$ & $292(26)$ & $-19(22)$ & $84(22)$ & $32(24)$ \\
$\mathrm{Cl}(2)$ & $236(26)$ & $294(29)$ & $384(30)$ & $36(24)$ & $17(23)$ & $-10(23)$ \\
$\mathrm{N}(1)$ & $180(80)$ & $166(87)$ & $358(99)$ & $-10(73)$ & $124(73)$ & $-27(72)$ \\
$\mathrm{C}$ & $358(123)$ & $178(104)$ & $125(100)$ & $53(77)$ & $34(92)$ & $7(93)$ \\
$\mathrm{N}(2)$ & $184(82)$ & $291(97)$ & $280(90)$ & $51(84)$ & $29(71)$ & $52(83)$ \\
\hline
\end{tabular}

Table 3. Anisotropic displacement parameters $\left(\mathrm{pm}^{2}\right)$ for $\mathrm{Hg}_{2}(\mathrm{NCN}) \mathrm{Cl}_{2}$ (standard deviations in parentheses). The components $\mathrm{U}_{\mathrm{ij}}$ refer to a displacement factor of the form $\exp \left\{-2 \pi^{2}\left(\mathrm{U}_{11} h^{2} a^{* 2}+\cdots+\right.\right.$ $\left.\left.2 \mathrm{U}_{23} k l b^{*} c^{*}\right)\right\}$.
Table 4. Selected interatomic distances (pm) and bond angles $\left(^{\circ}\right)$ for $\mathrm{Hg}_{2}(\mathrm{NCN}) \mathrm{Cl}_{2}$.

\begin{tabular}{|c|c|c|c|}
\hline $\mathrm{Hg}(1)-\mathrm{N}(1)$ & $207.0(16)$ & $\mathrm{Hg}(1)-\mathrm{N}(2)$ & 207.4(16) \\
\hline $\mathrm{Hg}(2)-\mathrm{N}(1)$ & $206.6(16)(2 \times)$ & $\mathrm{Hg}(2)-\mathrm{Cl}(1)$ & $295.9(5) \quad(2 \times)$ \\
\hline $\mathrm{Hg}(3)-\mathrm{Cl}(2)$ & $233.8(5) \quad(2 \times)$ & $\mathrm{N}(1)-\mathrm{C}$ & 124(3) \\
\hline $\mathrm{C}-\mathrm{N}(2)$ & $122(3)$ & & \\
\hline \multicolumn{2}{|c|}{$\mathrm{N}(1)-\mathrm{Hg}(1)-\mathrm{N}(2)$} & \multicolumn{2}{|c|}{$\mathrm{N}(1)-\mathrm{Hg}(2)-\mathrm{N}(1) \quad 180$} \\
\hline $\mathrm{C}-\mathrm{N}(1)-\mathrm{Hg}(1)$ & $113.5(14)$ & \multicolumn{2}{|c|}{$\mathrm{C}-\mathrm{N}(1)-\mathrm{Hg}(2) \quad 123.5(15)$} \\
\hline $\mathrm{C}-\mathrm{N}(2)-\mathrm{Hg}(1)$ & $124.4(15)$ & \multirow{2}{*}{\multicolumn{2}{|c|}{$\begin{array}{l}\mathrm{Hg}(2)-\mathrm{N}(1)-\mathrm{Hg}(1) 123.0(8) \\
\mathrm{Cl}(2)-\mathrm{Hg}(3)-\mathrm{Cl}(2) 180\end{array}$}} \\
\hline $\mathrm{N}(1)-\mathrm{C}-\mathrm{N}(2)$ & $177(2)$ & & \\
\hline $\mathrm{Cl}(1)-\mathrm{Hg}(2)-\mathrm{Cl}($ & (1) 180 & & \\
\hline
\end{tabular}

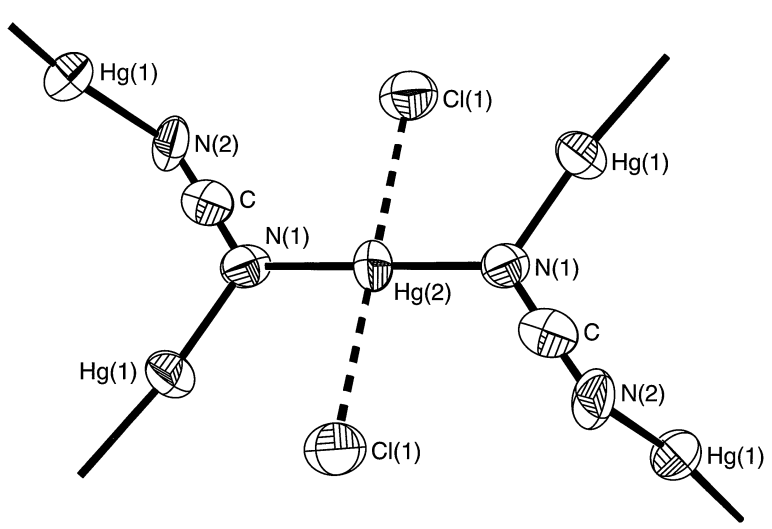

Fig. 1. Thermal ellipsoid plot (90\% probability) of the atomic coordinations in $\mathrm{Hg}_{2}(\mathrm{NCN}) \mathrm{Cl}_{2}$; the incorporated $\mathrm{HgCl}_{2}$ molecule has been omitted for clarity.

symmetry, is also bonded linearly to two N(1) nitrogen atoms; thus, $\operatorname{Hg}(2)-\mathrm{N}(1)=206.6(16) \mathrm{pm}$ and $\mathrm{N}(1)-\mathrm{Hg}(2)-\mathrm{N}(1)=180^{\circ}$ by space group symmetry. Remarkably, it is the $\mathrm{Hg}(2)$ atom which links the above-mentioned zigzag chains made from $\mathrm{Hg}(1)$ and $\mathrm{NCN}^{2-}$ units (Fig. 1). Also, the four $\mathrm{Hg}-\mathrm{N}$ distances are almost identical $(207 \mathrm{pm})$ and agree very well with those found in related materials (205 $211 \mathrm{pm})[11,15]$.

$\mathrm{Hg}(3)$ is not involved in the $\mathrm{Hg}-\mathrm{NCN}$ bonding but linearly coordinated by two $\mathrm{Cl}^{-}$at a distance of $\mathrm{Hg}(3)-\mathrm{Cl}(2)=233.8(5) \mathrm{pm}$ and an angle of $\mathrm{Cl}(2)-$

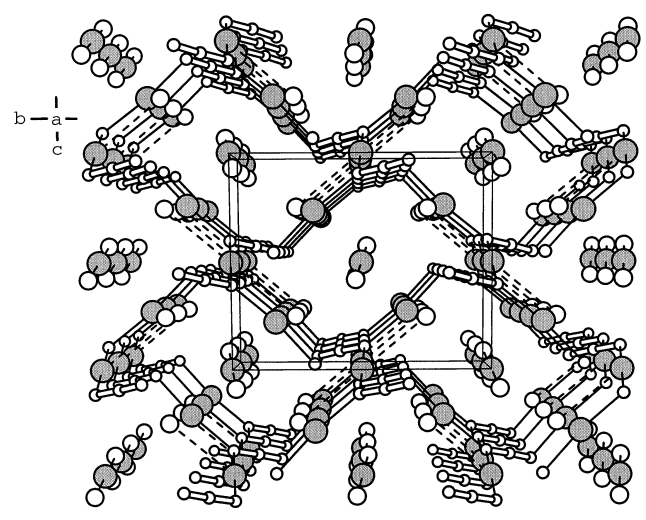

Fig. 2. Packing of $\mathrm{Hg}_{2}(\mathrm{NCN}) \mathrm{Cl}_{2}$; the big circles are $\mathrm{Hg}$ atoms, the medium circles $\mathrm{Cl}^{-}$anions and the small units $\mathrm{NCN}^{2-}$ anions.

$\mathrm{Hg}(3)-\mathrm{Cl}(2)=180^{\circ}$ by space group symmetry. Since this is very similar to the situation in pure $\mathrm{HgCl}_{2}$ (Hg-Cl: 227 and 229 pm, Cl-Hg-Cl: 178.6 ${ }^{\circ}$ [16], the notion of an isolated molecular $\mathrm{HgCl}_{2}$ species is justified; the one additional interaction of $\mathrm{Cl}(2)$ with $\mathrm{Hg}(1)$ is insignificant (305.5(5) pm). In addition, there is a free $\mathrm{Cl}^{-}$anion in the leftover coordination sites around $\mathrm{Hg}(2)$ at 295.9(5) and around $\mathrm{Hg}(3)$ at 309.5(5) pm.

Coming back to the $\mathrm{NCN}^{2-}$ unit, the individual distances of $\mathrm{N}(1)-\mathrm{C}=124(3) \mathrm{pm}$ and $\mathrm{C}-\mathrm{N}(2)=$ 122(3) $\mathrm{pm}$ as well as the N(1)-C-N(2) angle of $177(2)^{\circ}$ show it to be a carbodiimide species, similar to the one found in $\mathrm{HgNCN}(\mathrm{I})$ [5]. We note, however, that $\mathrm{N}(2)$ is one-coordinate but $\mathrm{N}(1)$ is two-coordinate to $\mathrm{Hg}$ (see also Discussion).

The total structural motif of $\mathrm{Hg}_{2}(\mathrm{NCN}) \mathrm{Cl}_{2}$ is shown in Fig. 2. Mercury atoms and carbodiimide units form an unprecedented two-dimensional network from $\mathrm{Hg}(1)-\mathrm{NCN}-\mathrm{Hg}(1)$ chains cross-linked by $\mathrm{Hg}(2)$ atoms. As a result, there are 20 -membered rings stacked on top of each other along the $a$ 
Table 5. Crystallographic data for $\mathrm{Hg}_{3}(\mathrm{NCN})_{2} \mathrm{Cl}_{2}$.

Formula; molar mass $\mathrm{Hg}_{3}(\mathrm{NCN})_{2} \mathrm{Cl}_{2} ; 752.73 \mathrm{~g} / \mathrm{mol}$

Crystal color and form

Lattice constant Colorless rectangular prism

$$
a=702.0(2) \mathrm{pm}
$$$$
b=1078.5(2) \mathrm{pm}
$$$$
c=1050.3(2) \mathrm{pm}
$$

Cell volume

Space group; $Z$

$\mathrm{X}$-ray density

$F(000)$

Diffractometer

Temperature

No of reflections

Independent refls

Octants; max. $\theta$

Absorption coeff.

Abs. correction

Twin structure

Structure solution

Structure refinement

No. of intensities

No. of variables

No. of restraints

Weighting scheme

Min., max. residual electron density

$R_{1}, w R_{2}$

Goodness of fit
Pca2 $_{1}$ (No. 29); 4

$6.288 \mathrm{~g} / \mathrm{cm}^{3}$

1256

Bruker SMART CCD diffractometer with $\mathrm{Mo}-\mathrm{K}_{\alpha}$ radiation, graphite monochromator

293(1) K

$9910\left(R_{\mathrm{eq}}=0.0924\right)$

1977

$-9<h<9,-14<k<14$,

$-1 \overline{4} \leq 1 \leq 13 ; 28.32^{\circ}$

$58.386 \mathrm{~mm}^{-1}$

multi-scan (SADABS)

inversion twin, $\mathrm{BASF}=0.47(2)$

Direct Methods (SHELXS-97)

Least-squares method on $F^{2}$,

1977

71

1 (floating origin)

$w=1 /\left[\sigma\left(F_{0}^{2}\right)(0.0139 P)^{2}\right]$,

where $P=\left(\max \left(F_{0}^{2}, 0\right)+2 \mathrm{~F}_{0}^{2}\right) / 3$

$-1.539,1.821 \mathrm{e} / \AA^{3}$

$0.0380,0.0651$

1.015
Pca $1(3) \cdot 10^{6} \mathrm{pm}^{3}$

Full matrix

(proximity of $\mathrm{Hg}$ )

axis. The channels thus formed are filled with $\mathrm{HgCl}_{2}$ molecules and $\mathrm{Cl}^{-}$anions.

\subsection{The crystal structure of $\mathrm{Hg}_{3}(\mathrm{NCN})_{2} \mathrm{Cl}_{2}$}

Upon refinement in the acentric space group $P c a 2_{1}$, it was realized that the individual crystal (just like all others) was an inversion twin. The corresponding twin refinement converged to a batch scale factor of $0.47(2)$, i. e., approximately equal contributions of the two twin compounds. By doing so, $R_{1}$ reduced from 0.0433 to 0.0380 by slightly changing the spatial parameters of the light atoms only. Due to the very strong absorption, a refinement including anisotropic displacement parameters for $\mathrm{Hg}$ and $\mathrm{Cl}$ and isotropic ones for $\mathrm{N}$ and $\mathrm{C}$ turned out to be the most reasonable.

The crystallographic data of $\mathrm{Hg}_{3}\left(\mathrm{NCN}_{2} \mathrm{Cl}_{2}\right.$ are summarized in Table 5, and Tables 6 and 7 offer po-

Table 6. Positional parameters (all atoms on $4 a$ ) and isotropic displacement parameters $\left(\mathrm{U}_{\mathrm{eq}}\right.$ in $\mathrm{pm}^{2}$, a third of the trace of the orthogonalized $\mathrm{U}_{\mathrm{ij}}$ tensor) for $\mathrm{Hg}_{3}(\mathrm{NCN})_{2} \mathrm{Cl}_{2}$ (standard deviations in parentheses).

\begin{tabular}{lllll}
\hline Atom & $x$ & $y$ & $z$ & $\mathrm{U}_{\text {eq }}$ \\
\hline $\mathrm{Hg}(1)$ & $0.7065(1)$ & $0.08577(7)$ & $0.95711(7)$ & $296(2)$ \\
$\mathrm{Hg}(2)$ & $0.98652(9)$ & $0.44557(6)$ & $0.00562(8)$ & $236(2)$ \\
$\mathrm{Hg}(3)$ & $0.23031(9)$ & $0.20550(6)$ & $0.64448(7)$ & $247(2)$ \\
$\mathrm{Cl}(1)$ & $0.0697(6)$ & $0.2006(4)$ & $0.8980(5)$ & $275(9)$ \\
$\mathrm{Cl}(2)$ & $0.6336(6)$ & $0.2972(4)$ & $0.0809(5)$ & $324(11)$ \\
$\mathrm{N}(1)$ & $0.155(2)$ & $0.017(1)$ & $0.603(1)$ & $193(31)$ \\
$\mathrm{C}(1)$ & $0.105(2)$ & $0.956(2)$ & $0.702(2)$ & $209(38)$ \\
$\mathrm{N}(2)$ & $0.044(2)$ & $0.906(2)$ & $0.788(1)$ & $231(34)$ \\
$\mathrm{N}(3)$ & $0.150(2)$ & $0.385(1)$ & $0.158(1)$ & $164(28)$ \\
$\mathrm{C}(2)$ & $0.159(2)$ & $0.440(2)$ & $0.260(2)$ & $255(41)$ \\
$\mathrm{N}(4)$ & $0.182(2)$ & $0.498(2)$ & $0.357(2)$ & $316(40)$ \\
\hline
\end{tabular}

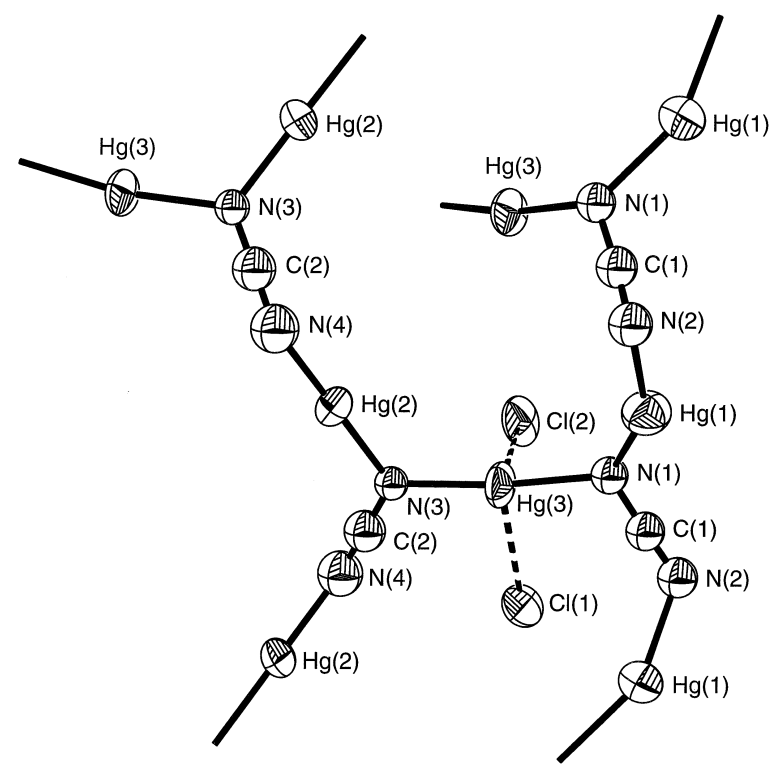

Fig. 3. Thermal ellipsoid plot (90\% probability) of the atomic coordinations in $\mathrm{Hg}_{3}(\mathrm{NCN})_{2} \mathrm{Cl}_{2}$.

sitional and isotropic as well as anisotropic displacement parameters $(\mathrm{Hg}, \mathrm{Cl})$. Important interatomic distances are listed in Table 8.

Fig. 3 shows the individual atomic coordinations in $\mathrm{Hg}_{3}(\mathrm{NCN})_{2} \mathrm{Cl}_{2}$ using displacement ellipsoids. $\mathrm{Hg}(1)$ is bonded to $\mathrm{N}(1)$ at 213.0(14) pm and to $\mathrm{N}(2)$ at $211.4(15) \mathrm{pm}$; the widened $\mathrm{Hg}-\mathrm{N}$ bond lengths find their expression in the significantly kinked bond angle $\mathrm{N}(1)-\mathrm{Hg}-\mathrm{N}(2)$ of $151.1(6)^{\circ}$. Just like in $\mathrm{Hg}_{2}(\mathrm{NCN}) \mathrm{Cl}_{2}$, there are infinite zigzag chains built from $\mathrm{Hg}(1)$ and $\mathrm{NCN}^{2-}$ units along the $c$ axis. A 


\begin{tabular}{llllllr}
\hline Atom & $\mathrm{U}_{11}$ & $\mathrm{U}_{22}$ & $\mathrm{U}_{33}$ & $\mathrm{U}_{23}$ & $\mathrm{U}_{13}$ & $\mathrm{U}_{12}$ \\
\hline $\mathrm{Hg}(1)$ & $365(4)$ & $285(4)$ & $239(4)$ & $13(4)$ & $-38(3)$ & $26(3)$ \\
$\mathrm{Hg}(2)$ & $280(3)$ & $207(3)$ & $220(3)$ & $37(3)$ & $-18(3)$ & $41(3)$ \\
$\mathrm{Hg}(3)$ & $321(3)$ & $114(3)$ & $305(4)$ & $-13(3)$ & $11(3)$ & $-33(3)$ \\
$\mathrm{Cl}(1)$ & $350(23)$ & $244(23)$ & $231(21)$ & $-76(20)$ & $25(19)$ & $8(19)$ \\
$\mathrm{Cl}(2)$ & $396(25)$ & $133(22)$ & $442(28)$ & $-40(23)$ & $99(23)$ & $-49(21)$ \\
\hline
\end{tabular}

Table 7. Anisotropic displacement parameters $\left(\mathrm{pm}^{2}\right)$ for $\mathrm{Hg}_{3}(\mathrm{NCN})_{2} \mathrm{Cl}_{2}$ (standard deviations in parentheses). The components $\mathrm{U}_{\mathrm{ij}}$ refer to a displacement factor of the form $\exp \left\{-2 \pi^{2}\left(\mathrm{U}_{11} h^{2} a^{* 2}\right.\right.$ $\left.\left.+\cdots+2 \mathrm{U}_{23} k l b^{*} c^{*}\right)\right\}$.

Table 8. Selected interatomic distances (pm) and bond angles $\left({ }^{\circ}\right)$ for $\mathrm{Hg}_{3}(\mathrm{NCN})_{2} \mathrm{Cl}_{2}$.

\begin{tabular}{llll}
\hline $\mathrm{Hg}(1)-\mathrm{N}(2)$ & $211.4(15)$ & $\mathrm{Hg}(1)-\mathrm{N}(1)$ & $213.0(14)$ \\
$\mathrm{Hg}(1)-\mathrm{Cl}(2)$ & $267.4(5)$ & $\mathrm{Hg}(1)-\mathrm{Cl}(1)$ & $290.2(5)$ \\
$\mathrm{Hg}(2)-\mathrm{N}(4)$ & $205.2(16)$ & $\mathrm{Hg}(2)-\mathrm{N}(3)$ & $207.3(13)$ \\
$\mathrm{Hg}(2)-\mathrm{Cl}(1)$ & $293.2(5)$ & $\mathrm{Hg}(3)-\mathrm{N}(3)$ & $211.5(13)$ \\
$\mathrm{Hg}(3)-\mathrm{N}(1)$ & $214.4(14)$ & $\mathrm{Hg}(3)-\mathrm{Cl}(2)$ & $282.0(4)$ \\
$\mathrm{Hg}(3)-\mathrm{Cl}(1)$ & $289.2(5)$ & $\mathrm{Hg}(3)-\mathrm{Cl}(1)$ & $294.5(5)$ \\
$\mathrm{C}(1)-\mathrm{N}(2)$ & $113(2)$ & $\mathrm{C}(1)-\mathrm{N}(1)$ & $128(2)$ \\
$\mathrm{N}(3)-\mathrm{C}(2)$ & $123(2)$ & $\mathrm{C}(2)-\mathrm{N}(4)$ & $120(2)$ \\
$\mathrm{N}(1)-\mathrm{Hg}(3)-\mathrm{N}(3)$ & $168.2(5)$ & $\mathrm{N}(3)-\mathrm{Hg}(2)-\mathrm{N}(4)$ & $178.2(6)$ \\
$\mathrm{N}(1)-\mathrm{Hg}(1)-\mathrm{N}(2)$ & $151.1(6)$ & $\mathrm{Hg}(1)-\mathrm{N}(1)-\mathrm{Hg}(3)$ & $121.7(6)$ \\
$\mathrm{Hg}(2)-\mathrm{N}(3)-\mathrm{Hg}(3)$ & $117.2(6)$ & $\mathrm{C}(1)-\mathrm{N}(1)-\mathrm{Hg}(1)$ & $116.2(12)$ \\
$\mathrm{C}(1)-\mathrm{N}(1)-\mathrm{Hg}(3)$ & $113.0(12)$ & $\mathrm{C}(1)-\mathrm{N}(2)-\mathrm{Hg}(1)$ & $116.3(13)$ \\
$\mathrm{C}(2)-\mathrm{N}(3)-\mathrm{Hg}(2)$ & $123.5(13)$ & $\mathrm{C}(2)-\mathrm{N}(3)-\mathrm{Hg}(3)$ & $118.6(13)$ \\
$\mathrm{C}(2)-\mathrm{N}(4)-\mathrm{Hg}(2)$ & $136.2(14)$ & $\mathrm{N}(1)-\mathrm{C}(1)-\mathrm{N}(2)$ & $174(2)$ \\
$\mathrm{N}(3)-\mathrm{C}(2)-\mathrm{N}(4)$ & $175(2)$ & & \\
\hline
\end{tabular}

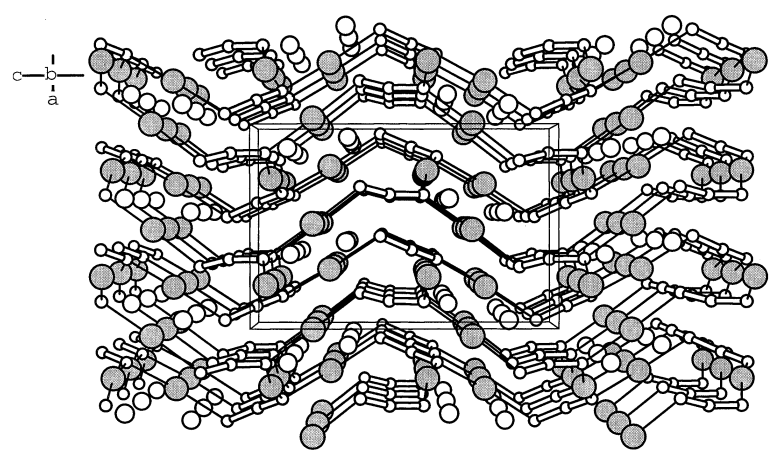

Fig. 4. Same as in Fig. 2 but for $\mathrm{Hg}_{3}(\mathrm{NCN})_{2} \mathrm{Cl}_{2}$.

similar role is played by $\mathrm{Hg}(2)$ but with shorter bond lengths $(\mathrm{Hg}(2)-\mathrm{N}(3)=207.3(13), \mathrm{Hg}(2)-\mathrm{N}(4)=$ 205.2(16) $\mathrm{pm}$ ) and, consequently, an almost linear angle of $\mathrm{N}(3)-\mathrm{Hg}(2)-\mathrm{N}(4)=178.2(6)^{\circ}$. Additionally, the $\mathrm{Hg}(3)$ atoms connect the two zigzag chains by two bonds to $\mathrm{N}(1)$ at $214.4(14) \mathrm{pm}$ and to $\mathrm{N}(3)$ at 211.4(14) pm; the bridging angle $\mathrm{N}(1)-\mathrm{Hg}(3)-\mathrm{N}(3)$ is $168.2(6)^{\circ}$. Also, there are two wide contacts of (almost) free chlorine ions to $\mathrm{Hg}$, namely $\mathrm{Cl}(1)$ and $\mathrm{Cl}(2)$ at $267-295 \mathrm{pm}$.

The lack of inversion symmetry in $\mathrm{Hg}_{3}(\mathrm{NCN})_{2}$ $\mathrm{Cl}_{2}$ is reflected by the presence of two symmetryinequivalent $\mathrm{NCN}^{2-}$ groups. Whereas the almost linear $\left(174(2)^{\circ}\right) \mathrm{N}(1)-\mathrm{C}(1)-\mathrm{N}(2)$ group can be considered a cyanamide unit because of the two different bond lengths, $\mathrm{N}(1)-\mathrm{C}(1)=128(2)$ and $\mathrm{C}(1)$ $\mathrm{N}(2)=113(2) \mathrm{pm}$, which are close to a single and triple $\mathrm{C}-\mathrm{N}$ bond, the $\mathrm{N}(3)-\mathrm{C}(2)-\mathrm{N}(4)$ group is also linear $\left(175(2)^{\circ}\right)$ but contains two $\mathrm{C}-\mathrm{N}$ double bonds: $\mathrm{N}(3)-\mathrm{C}(2)=123(2)$ and $\mathrm{C}(2)-\mathrm{N}(4)=120(2) \mathrm{pm}$; the structural designation of $\mathrm{N}(3)-\mathrm{C}(2)-\mathrm{N}(4)$ as a carbodiimide species is justified. We mention that this is the first occurrence of both cyanamide (known from the structures of $\mathrm{PbNCN}$ [17] and $\mathrm{HgNCN}$ (II) [6]) and carbodiimide units (known from $\mathrm{HgNCN}(\mathrm{I})$ [5]) in the same crystal structure of an inorganic network.

Fig. 4 presents the whole crystal structure. Mercury atoms and $\mathrm{NCN}^{2-}$ units form also 20-membered rings, but the cavities are much smaller than those in $\mathrm{Hg}_{2}(\mathrm{NCN}) \mathrm{Cl}_{2}$ since only chloride ions need to be hosted in the channels.

\section{Discussion}

The structural chemistry of systems with $\mathrm{NCN}^{2-}$ and $\mathrm{Hg}^{2+}$ units has been characterized so far by two binding modes, schematically given in Scheme 1: mode (a) is found in mercury carbodiimide, $\operatorname{HgNCN}(\mathrm{I})$, mode (b) in mercury cyanamide, $\mathrm{HgNCN}(\mathrm{II})$. To generate the novel structural networks observed in $\mathrm{Hg}_{2}(\mathrm{NCN}) \mathrm{Cl}_{2}$ and $\mathrm{Hg}_{3}(\mathrm{NCN})_{2} \mathrm{Cl}_{2}$, the new binding mode (c) is necessary. The binding mode (d) has, so far, never been observed experimentally, but quantum-chemical calculations from first principles suggest this coordinative scenario as one possible (and energetically high-lying) transition structure when going from (a) to (b) [6].

The structural analysis makes it clear that the title compounds are characterized by a stoichiometrically identical $\left[\mathrm{Hg}_{3}(\mathrm{NCN})_{2}\right]^{2+}$ cationic backbone which is built up from 20-membered rings. Thus, the chemical formulas could be rewritten as $\mathrm{Hg}_{2}(\mathrm{NCN}) \mathrm{Cl}_{2}=1 / 2 \cdot\left\{\left[\mathrm{Hg}_{3}(\mathrm{NCN})_{2}\right] \mathrm{Cl}_{2} \cdot \mathrm{HgCl}_{2}\right\}$ and as $\mathrm{Hg}_{3}(\mathrm{NCN})_{2} \mathrm{Cl}_{2}=\left[\mathrm{Hg}_{3}(\mathrm{NCN})_{2}\right] \mathrm{Cl}_{2}$. While the N- 


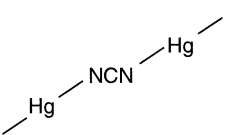

(a)

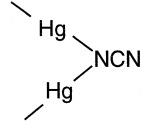

(b)

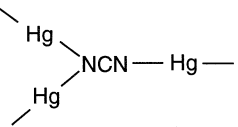

(c)

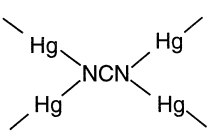

(d)
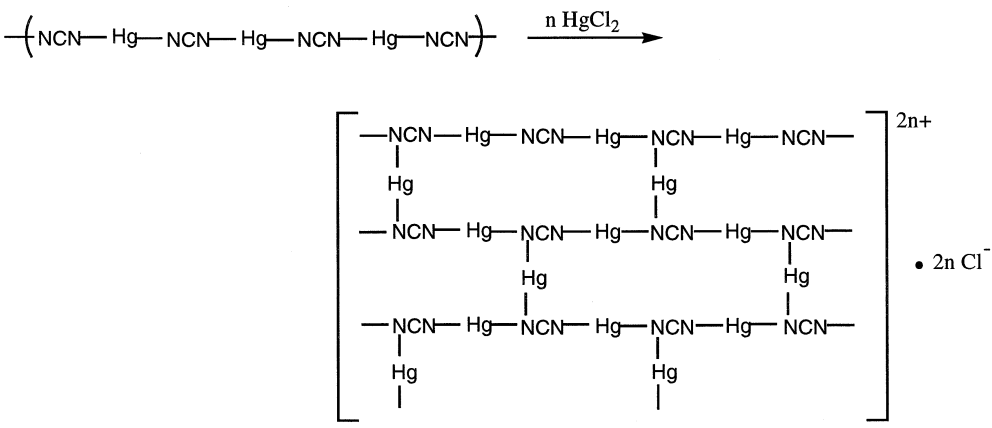

Scheme 2. The $\left[\mathrm{Hg}_{3}(\mathrm{NCN})_{2}\right]^{2+}$

Scheme 1. The coordination modes between $\mathrm{NCN}^{2-}$ and $\mathrm{Hg}^{2+}$.
$\mathrm{C}-\mathrm{N}$ and $-\mathrm{N}-\mathrm{Hg}-\mathrm{N}$ - bond distances and angles are relatively constant for both compounds, the cavities (and channels) thus formed seem to be remarkably flexible; flexible enough, at least, to adapt to either $\mathrm{Cl}^{-}, \mathrm{HgCl}_{2}$, or a combination of the two. It remains to be seen whether the backbone can host other species such as $\mathrm{Br}^{-}, \mathrm{HgBr}_{2}$ etc. as well.

The generation of the backbone itself is schematically depicted in Scheme 2.

As stated before, the new binding mode (c) is needed to set up the 20-membered rings composed of $\mathrm{NCN}^{2-}$ and $\mathrm{Hg}^{2+}$. While the sketch alludes to the notion of an open material, an inspection of the packing efficiency yields an astonishing result. Based on the tabulated [18] volume increment of $\mathrm{Hg}^{2+}\left(8 \mathrm{~cm}^{3} / \mathrm{mol}\right)$, it is possible to calculate an average volume increment, on the basis of the crystal structures of $\mathrm{HgNCN}(\mathrm{I})$ and $\mathrm{HgNCN}(\mathrm{II})$, for the $\mathrm{NCN}^{2-}$ unit, namely $28.1 \mathrm{~cm}^{3} / \mathrm{mol}$; thus, $\mathrm{NCN}^{2-}$ is similar in spatial requirement to $\mathrm{S}^{2-}\left(29 \mathrm{~cm}^{3} / \mathrm{mol}\right)$. Including the value for $\mathrm{Cl}^{-}\left(20 \mathrm{~cm}^{3} / \mathrm{mol}\right)$, the theoretical molar volume of $\mathrm{Hg}_{2}(\mathrm{NCN}) \mathrm{Cl}_{2}$ should be $84.1 \mathrm{~cm}^{3} / \mathrm{mol}$ - the experimental volume is even smaller by $1 \%$, though. Likewise, $\mathrm{Hg}_{3}(\mathrm{NCN})_{2} \mathrm{Cl}_{2}$ should require $120.2 \mathrm{~cm}^{3} / \mathrm{mol}$ but is more dense by $0.4 \%$; as it seems, the packing efficiency is clearly optimized.

It is not known, up to now, whether compounds of the above kind may serve useful in the synthesis of functional materials exhibiting cavities of diverse shapes and sizes. The rational design of such coordination networks continues to be a challenging goal for crystal engineers [10, 19]. Samples of $\mathrm{Hg}_{2}(\mathrm{NCN}) \mathrm{Cl}_{2}$ might nonetheless be subjected to the attempt of exchanging the hosted $\mathrm{HgCl}_{2}$ molecular species $\left(48 \mathrm{~cm}^{3} / \mathrm{mol}\right.$ ) against (substituted) hydrocarbons of similar size. In any case, the existence of $\mathrm{Hg}_{2}(\mathrm{NCN}) \mathrm{Cl}_{2}$ and $\mathrm{Hg}_{3}(\mathrm{NCN})_{2} \mathrm{Cl}_{2}$ shows that it is possible to generate new channels and cavities using $\mathrm{NCN}^{2-}$.

\section{Acknowledgements}

It is a pleasure to thank Klaus Kruse for the collection of the X-ray intensities as well as the Fonds der Chemischen Industrie for continuous support.

[4] a) F. P. Bowden, H. M. Montagu-Pollock, Nature 191, 556 (1961); b) M. Becker, J. Nuss, M. Jansen, Z. Naturforsch. 55b, 383 (2000).

[5] a) S. K. Deb, A. D. Yoffe, Trans. Faraday Soc. 55, 106 (1958); b) M. Becker, M. Jansen, Z. Anorg. Allg. Chem. 626, 1639 (2000). 
[6] X. Liu, P. Müller, P. Kroll, R. Dronskowski, Inorg. Chem. 41, 4259 (2002).

[7] R. Dronskowski, Z. Naturforsch. 50b, 1245 (1995).

[8] M. Becker, M. Jansen, Acta Crystallogr. C57, 347 (2001).

[9] R. Riedel, A. Greiner, G. Miehe, W. Dreßler, H. Fueß, J. Bill and F. Aldinger, Angew. Chem. Int. Ed. 36, 603 (1997).

[10] a) M. S. Zaworotko, Chem. Commun. 1 (2001); b) B. Holliday, C. Mirkin, Angew. Chem. Int. Ed. 40, 2022 (2001); c) A. K. Cheetham, G. Férey, T. Loiseau, Angew. Chem. Int. Ed. 38, 3268 (1999).

[11] D. Breitinger, K. Brodersen, Angew. Chem. Int. Ed. 9, 357 (1970).

[12] D. Bebout, A. DeLanoy, D. Ehmann, M. Kasner, D. Parrish, R. Butcher, Inorg. Chem. 37, 2952 (1998).
[13] SADABS, SMART and SAINT, Bruker AXS Inc., Madison Wisconsin, USA.

[14] G. M. Sheldrick, SHELXS97 and SHELXL97, University of Göttingen, Germany.

[15] a) H. Schumann, J. Cottfriedsen, S. Dechert, F. Girgsdies, Z. Anorg. Allg. Chem. 626, 747 (2000); b) N. Masciochi, G. A. Ardizzoia, A. Maspero, G. Lamonica, A. Sironi, Inorg. Chem. 38, 3657 (1999).

[16] V. Subramanian, K. Seff, Acta. Crystallogr. B36, 2132 (1980).

[17] X. Liu, A Decker, D. Schmitz, R. Dronskowski, Z. Anorg. Allg. Chem. 626, 103 (2000).

[18] W. Biltz, Raumchemie der festen Stoffe, Verlag von Leopold Voss, Leipzig (1934).

[19] a) L. R. MacGillivray, J. L. Atwood, Nature 389, 469 (1997); b) P. Holy, J. Závada, I. Císarová and J. Podlaha, Angew. Chem. Int. Ed. 38, 381 (1999). 